\title{
Antisense RNA Amplification for Target Assessment of Total mRNA from a Single Cell
}

\author{
Jacqueline Morris, ${ }^{1}$ Thomas J. Bell, ${ }^{1}$ Peter T. Buckley, ${ }^{2}$ and James H. Eberwine ${ }^{3,4}$ \\ ${ }^{1}$ Department of Pharmacology, University of Pennsylvania, Philadelphia, Pennsylvania 19104; ${ }^{2}$ Janssen \\ Pharmaceuticals, Radnor, Pennsylvania 19087; ${ }^{3}$ Penn Genome Frontiers Institute, Department of Pharmacology, \\ University of Pennsylvania, Philadelphia, Pennsylvania 19104
}

This protocol describes how to amplify mRNA isolated from a single cell and then analyze its gene expression profile using polymerase chain reaction (PCR). Single-cell analysis is advantageous over studies of cell populations because it allows identification of a range of normal physiological states expressed by different cells of the same cell type without the confounding effects of averaging that result from measuring physiological states of cell populations. This is especially important when addressing questions of physiology in tissues, which comprises many different cell types. However, a single cell does not contain enough mRNA for all of the expressed transcripts to be detected or measured by any current molecular biology techniques. The antisense RNA (aRNA) amplification method was developed to amplify the picogram amounts of mRNA found within a single cell to microgram amounts of aRNA after three rounds of amplification. This aRNA can then easily be analyzed by microarray or next-generation sequencing. These methods allow identification of all expressed mRNA species within a single cell, including previously unknown mRNAs or those mRNAs specifically affected by a certain treatment. mRNA species of interest identified by these techniques can be further analyzed by designing primers targeting these species and performing PCR. cDNA synthesized from RNA at any stage in the aRNA amplification procedure, including material directly from collected unamplified cells, can be analyzed using PCR. Regardless of downstream applications, single-cell aRNA amplification is a powerful tool for studying single-cell physiological dynamics.

It is essential that you consult the appropriate Material Safety Data Sheets and your institution's Environmental Health and Safety Office for proper handling of equipment and hazardous materials used in this protocol.

RECIPE: Please see the end of this protocol for recipes indicated by $<R>$. Additional recipes can be found online at http://cshprotocols.cshlp.org/site/recipes.

Reagents

Agarose gel (1.5\%)

Ammonium acetate $(5 \mathrm{M})$

Diethylpyrocarbonate (DEPC) $-\mathrm{H}_{2} \mathrm{O}<\mathrm{R}>$

DNA ligase $(10 \mathrm{U} / \mu \mathrm{L})$

DNA polymerase I $(10 \mathrm{U} / \mu \mathrm{L})$

${ }^{4}$ Correspondence: eberwine@pharm.med.upenn.edu

(C) 2014 Cold Spring Harbor Laboratory Press

Cite this protocol as Cold Spring Harb Protoc; doi:10.1101/pdb.prot072454 
J. Morris et al.

dNTP mix (10 mm total; $2.5 \mathrm{~mm}$ each)

DTT (100 mM; supplied with Superscript III)

Ethanol (absolute; 200 proof)

Ethidium bromide

First-Strand Buffer (5×; supplied with Superscript III)

Glycogen $(5 \mathrm{mg} / \mathrm{mL})$

High-sensitivity DNA Kit (Agilent Technologies 5067-4626)

MegaClear Kit, including all buffers (Life Technologies AM1908)

MegaScript T7 In Vitro Transcription (IVT) Kit, including all buffers (Life Technologies AM1334)

MinElute Reaction Cleanup Kit, including all buffers (Qiagen 28206)

PCR primers (gene-specific; $10 \mu \mathrm{M}$ )

PCR primers (random; $0.05 \mathrm{mg} / \mathrm{mL}$ )

Platinum Taq PCR SuperMix (Life Technologies 11306016)

Primer T7-oligo (dT) $(100 \mathrm{ng} / \mu \mathrm{L})$

The sequence is GGAGGCCGGAGAATTGTAATACGACTCACTATAGGGAGACGCGTGTTTTTTTTTTTTTTTT TTTTTTTTV, where $V$ is any nucleotide except $T$.

RNA 6000 Pico Kit (Agilent Technologies 5067-1513) (optional; see Step 19.xvii)

RNase $\mathrm{H}(2 \mathrm{U} / \mu \mathrm{L})$

RNasin (40 U/ $\mu \mathrm{L}$; Promega)

Second-Strand Buffer (5×; Life Technologies 10812014)

Single cell of interest

Any cell of interest isolated by any method can be used. Isolation methods include micropipette suction, laser capture microdissection, fluorescence-activated cell sorting (FACS), or other microfluidics-based single-cell separation methods.

Sodium acetate (3 m, pH 5.0) (optional; see Step 17.iii)

SuperScript III Reverse Transcriptase (RT) (200 U/ $\mu$ L; Life Technologies 18080044)

T4 DNA polymerase $(5 \mathrm{U} / \mu \mathrm{L})$

Equipment

2100 Bioanalyzer (Agilent)

Dry bath incubator

Freezer $\left(-80^{\circ} \mathrm{C}\right)$

Gel imager

Heat blocks

Microcentrifuge

Microcentrifuge tubes

PCR tubes $(0.2 \mathrm{~mL})$

Thermocycler

\section{METHOD}

\section{Round 1}

\section{First-Strand cDNA Synthesis}

See Figure 1 for a schematic of the first, second, and third rounds of the aRNA procedure.

1. Collect the cell of interest into a 1.7-mL microcentrifuge tube containing $2 \mu \mathrm{L}$ of $5 \times$ First-Strand Buffer.

2. Measure the collection volume, and bring the total volume to $5 \mu \mathrm{L}$ with DEPC $-\mathrm{H}_{2} \mathrm{O}$. 


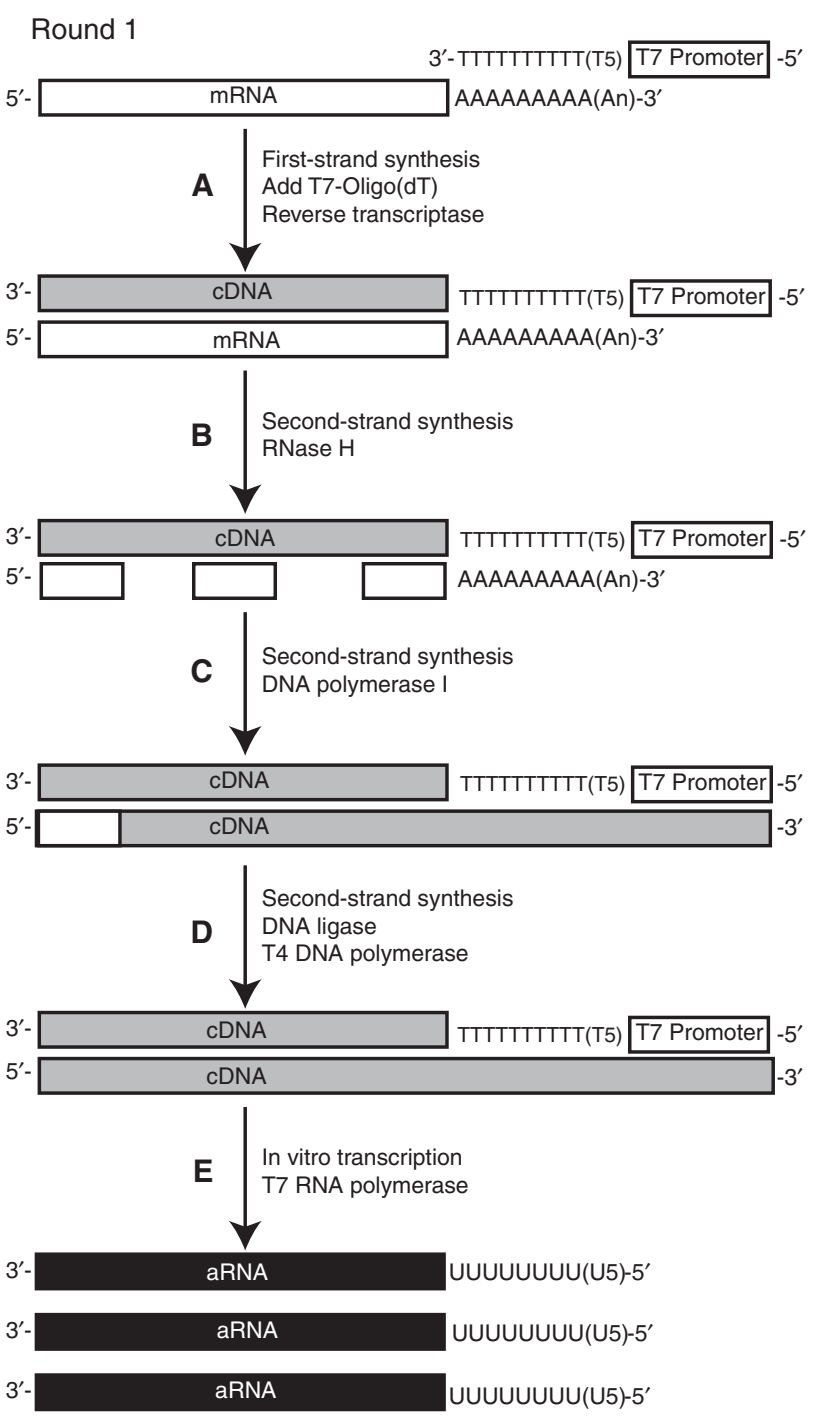

Round 2

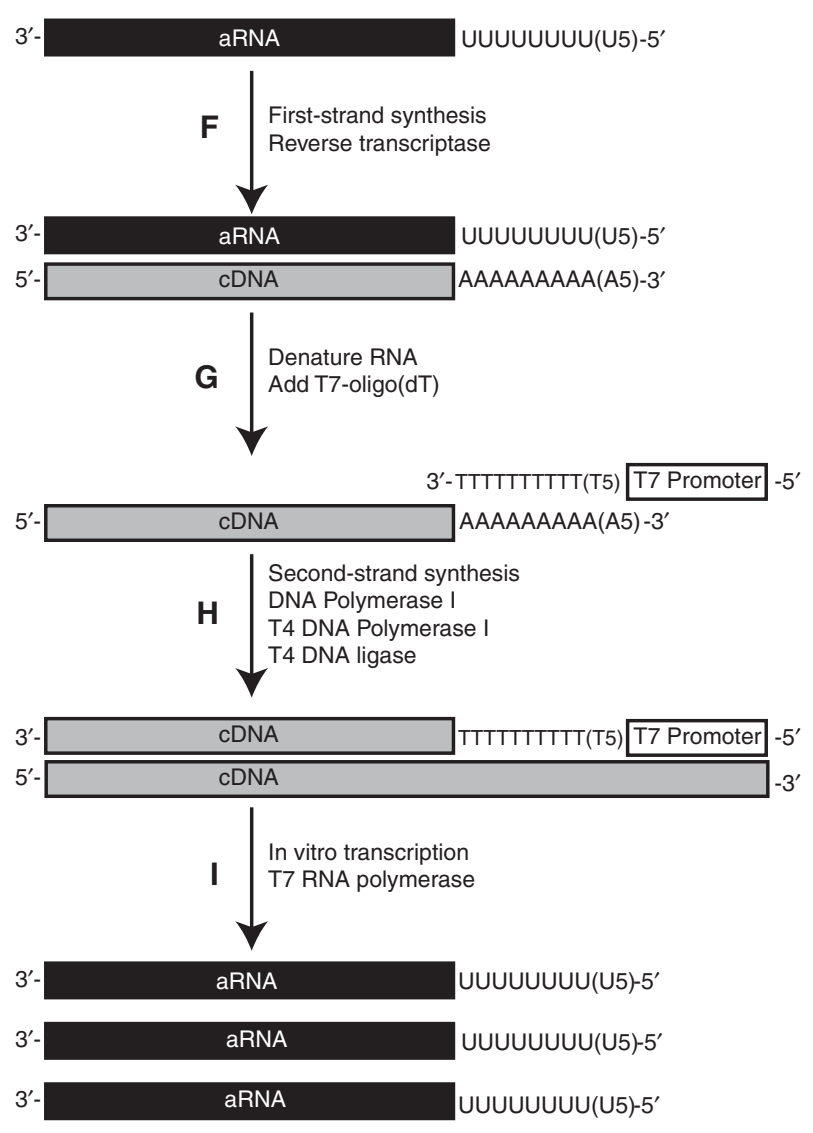

Round 3

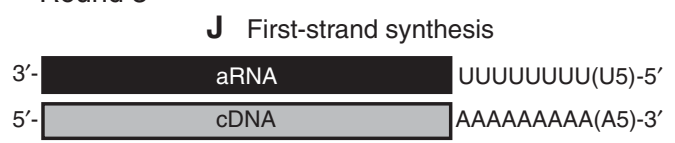

FIGURE 1. Schematic of the first and second rounds of the aRNA procedure. $(A)$ In the first round, first-strand cDNA synthesis from mRNA is primed upon binding of the poly $(\mathrm{T})$ portion of the T7-oligo(dT) primer to the poly $(\mathrm{A})$ tail of mRNA. Reverse transcriptase synthesizes a cDNA strand from this primer using the mRNA as template. $(B) \mathrm{RNase} H$ is then used to digest portions of the bound mRNA to create RNA fragments. (C) These are used by DNA Polymerase I to prime synthesis of DNA using the previously synthesized cDNA as template. Its $5^{\prime}$ to $3^{\prime}$ nuclease activity removes RNA fragments as it runs into them during synthesis and replaces them with a DNA strand. (D) DNA ligase then ligates any strands where replacement of the leading strand is incomplete and T4 polymerase fills in the gaps. $(E)$ The incorporated T7 promoter site is then used to synthesize thousands of copies of antisense RNA by T7 RNA polymerase from each DNA duplex (each representing a single mRNA molecule). $(F)$ In the second round, first-strand synthesis is primed by random primers instead of the T7-oligo(dT) since there is no longer a polyadenylated portion of the mRNA to which it can bind. A cDNA strand is synthesized by reverse transcriptase using the aRNA as template. (G) After RNA denaturation, second-strand synthesis is primed with the T7-oligo(dT) primer, which binds to the poly(A) portion of cDNA created in first-strand synthesis, $(H)$ and the second strand is synthesized by DNA Polymerase I. $(I)$ The incorporated T7 promoter is then used again for aRNA synthesis. (J) Finally, the aRNA is converted into cDNA, which is used as input into the PCR amplification of specific gens from this cDNA mixture (see Fig. 3). (Modified, with permission, from Dr. James H. Eberwine, 2012. (C) JoVE.) 
3. Incubate for $5 \mathrm{~min}$ at $70^{\circ} \mathrm{C}$ in a dry bath incubator.

This denatures any secondary structures in the mRNA.

4. Immediately place the sample on ice, and leave for at least $5 \mathrm{~min}$.

5. Assemble the following master mix on ice (volumes shown are for one reaction).

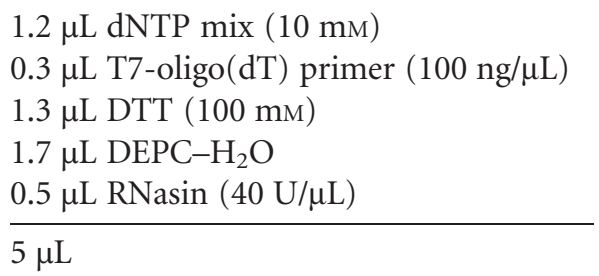

6. Add $5 \mu \mathrm{L}$ of the master mix to each $5-\mu \mathrm{L}$ sample, pipette to mix, and centrifuge briefly using a microcentrifuge.

7. Incubate at $42^{\circ} \mathrm{C}$ in a dry bath incubator for $5 \mathrm{~min}$.

8. Add $0.5 \mu \mathrm{L}$ of Superscript III RT, and pipette to mix.

9. Incubate at $42^{\circ} \mathrm{C}$ in a dry bath incubator for $1 \mathrm{~h}$.

10. Incubate at $70^{\circ} \mathrm{C}$ in a dry bath incubator for $15 \mathrm{~min}$.

This inactivates the Superscript III RT.

11. Proceed immediately to Step 12.

The DNA-RNA hybrids in this sample are susceptible to degradation and are required for priming DNA polymerase I in Step 12. Therefore, we recommend proceeding immediately to Step 12 without pausing. If desired, save $1 \mu \mathrm{L}$ of round 1 first-strand $C D N A$ for $P C R$ analysis (store at $-20^{\circ} \mathrm{C}$ ); this represents unamplified material.

\section{Second-Strand cDNA Synthesis}

12. Assemble the following master mix on ice (volumes shown are for one reaction):

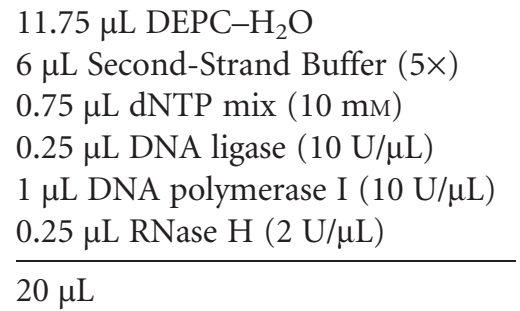

13. Add $20 \mu \mathrm{L}$ of the master mix to each $10.5-\mu \mathrm{L}$ first-strand reaction, mix thoroughly by pipetting, and centrifuge briefly using a microcentrifuge.

14. Incubate at $16^{\circ} \mathrm{C}$ in a dry bath incubator for $2 \mathrm{~h}$.

15. Add $1 \mu \mathrm{L}$ of T4 DNA polymerase $(5 \mathrm{U} / \mu \mathrm{L})$, mix by pipetting, and centrifuge briefly using a microcentrifuge.

16. Incubate at $16^{\circ} \mathrm{C}$ in a dry bath incubator for $10 \mathrm{~min}$.

17. Clean up the double-stranded DNA with the MinElute Kit. The following steps are based on the MinElute Reaction Cleanup Kit Protocol.

\section{Bind DNA to Column}

i. Place a MinElute column in the provided 2-mL collection tube.

ii. Bring the reaction volume up to $100 \mu \mathrm{L}$ by adding $\mathrm{DEPC}-\mathrm{H}_{2} \mathrm{O}$. 
iii. Add $300 \mu \mathrm{L}$ of Buffer ERC and mix.

A yellow mixture indicates that the proper $\mathrm{pH}$ has been maintained. If it is orange or violet, add $10 \mu \mathrm{L}$ of 3 s sodium acetate ( $\mathrm{pH}$ 5.0), and mix. The color of the mixture will turn yellow again, indicating that it is at the proper $\mathrm{pH}$ for DNA retention on the column.

iv. To bind DNA, apply the sample/Buffer ERC mixture to the column.

v. Centrifuge at $15,000 \mathrm{~g}$ for $30 \mathrm{sec}$ in a microcentrifuge.

vi. Discard the flowthrough and place the MinElute column back into the same collection tube.

\section{Wash DNA Bound to Column}

vii. To wash, add $500 \mu \mathrm{L}$ of Buffer PE to the MinElute column.

viii. Centrifuge at $15,000 \mathrm{~g}$ for $30 \mathrm{sec}$ in a microcentrifuge.

ix. Discard the flowthrough and place the MinElute column back in the same tube.

x. Repeat Steps 17.vii-17.ix.

xi. To remove residual ethanol, centrifuge for another $30 \mathrm{sec}$.

\section{Elute DNA Bound to Column}

xii. Place the MinElute column in a clean 1.7-mL microcentrifuge tube.

xiii. To elute DNA, add $11 \mu \mathrm{L}$ of DEPC- $\mathrm{H}_{2} \mathrm{O}$ directly to the center of the membrane.

xiv. Let the column stand for $2 \mathrm{~min}$.

xv. Centrifuge at $15,000 \mathrm{~g}$ for $30 \mathrm{sec}$. Do not discard.

This tube contains $\sim 10 \mu \mathrm{L}$ of clean double-stranded cDNA.

xvi. Measure the volume and bring the sample volume up to $10 \mu \mathrm{L}$ with DEPC $-\mathrm{H}_{2} \mathrm{O}$.

xvii. Transfer the sample to a 0.2-mL PCR tube, and proceed to Step 18.

Alternatively, double-stranded DNA can be stored at $-20^{\circ} \mathrm{C}$.

18. Synthesize aRNA from double-stranded DNA using the Ambion MEGAscript T7 In Vitro Transcription (IVT) Kit.

\section{Prepare Reagents}

i. Place the RNA Polymerase Enzyme mix on ice (do not vortex).

ii. Vortex the ribonucleotide mixture (ATP, CTP, GTP, UTP; $8.75 \mathrm{~mm}$ each), centrifuge briefly, and place on ice.

iii. Vortex the $10 \times$ Reaction Buffer until all particles are solubilized and keep at room temperature.

Keeping the buffer at room temperature is very important because the spermidine in chilled 10x Reaction Buffer can precipitate the template DNA and cause the reaction to fail.

\section{Assemble Reaction}

iv. Assemble the master mix below at room temperature by mixing the following reagents in the order listed (volumes shown are for one reaction).

$10 \mu \mathrm{L}$ ribonucleotide mixture ( $8.75 \mathrm{~mm}$ each)

$2.5 \mu \mathrm{L}$ Reaction Buffer $(10 \times)$

$2.5 \mu \mathrm{L}$ Enzyme Mix

$15 \mu \mathrm{L}$ 
v. Add $15 \mu \mathrm{L}$ of this master mix to each sample from Step 17. Pipette to mix and incubate in a thermocycler at $37^{\circ} \mathrm{C}$ for $14 \mathrm{~h}$ overnight.

vi. Transfer the reaction contents to a fresh $1.7-\mathrm{mL}$ microcentrifuge tube, and immediately proceed to Step 19.

19. Clean up aRNA with the Ambion Megaclear Kit.

\section{Bind RNA to Column}

i. Insert a Filter Cartridge into one of the supplied Collection and Elution Tubes.

ii. Bring the reaction volume up to $100 \mu \mathrm{L}$ by adding $75 \mu \mathrm{L}$ of Elution Solution to the IVT reaction.

iii. Add $350 \mu \mathrm{L}$ of Binding Solution Concentrate. Mix by tapping the tube.

iv. Add $250 \mu \mathrm{L}$ of $100 \%$ ethanol. Mix by tapping the tube.

v. Pipette the RNA mixture onto the Filter Cartridge.

vi. Centrifuge for $30 \mathrm{sec}$ at $10,000 \mathrm{~g}$ in a microcentrifuge to bind the RNA to the filter.

vii. Discard the flowthrough and reuse the Collection and Elution Tube.

\section{Wash RNA Bound to Column}

viii. Apply $500 \mu \mathrm{L}$ of Wash Solution to the column.

ix. Centrifuge at $10,000 \mathrm{~g}$ in a microcentrifuge for $30 \mathrm{sec}$.

x. Discard the flowthrough and place the column back in the same tube.

xi. Repeat Steps 19.viii-19.x once.

xii. Centrifuge again for $30 \mathrm{sec}$ in a microcentrifuge to remove residual ethanol from the filter.

\section{Elute RNA from Column}

xiii. Place the Filter Cartridge into a new Collection and Elution Tube.

xiv. Apply $50 \mu \mathrm{L}$ of nuclease-free water to the center of the Filter Cartridge. Close the cap of the tube.

xv. Incubate at $70^{\circ} \mathrm{C}$ in a dry bath incubator for $10 \mathrm{~min}$.

xvi. Centrifuge at $10,000 \mathrm{~g}$ in a microcentrifuge for $30 \mathrm{sec}$ and place eluate on ice.

xvii. Repeat Steps 19.xiii-19.xvi using the same Filter Cartridge and a new Collection and Elution Tube, and combine the eluates from the same sample into a single 1.7-mL microcentrifuge tube.

\section{Concentrate RNA by Ethanol Precipitation}

xviii. To the $100 \mu \mathrm{L}$ of eluate, add:

$2 \mu \mathrm{L}$ glycogen $(5 \mathrm{mg} / \mathrm{mL})$

$10 \mu \mathrm{L}$ (0.1 volumes) ammonium acetate $(5 \mathrm{M})$

$250 \mu \mathrm{L}$ ( 2.5 volumes) cold ethanol

xix. Pipette to mix and incubate at $-80^{\circ} \mathrm{C}$ for at least $30 \mathrm{~min}$.

$\mathrm{xx}$. Centrifuge at $10,000 \mathrm{~g}$ in a microcentrifuge for $20 \mathrm{~min}$ at $4^{\circ} \mathrm{C}$. 
Round 2

xxi. Remove supernatant and air-dry for no longer than $15 \mathrm{~min}$.

xxii. Resuspend pellet in $4 \mu \mathrm{L}$ DEPC $-\mathrm{H}_{2} \mathrm{O}$ and proceed immediately to the appropriate round of first-strand synthesis (either Step 20 or Step 44).

Clean aRNA can be stored at $-80^{\circ} \mathrm{C}$ for several weeks, but it is ideal to continue through the procedure until the sample is in a form of DNA, which is much more stable.

See Troubleshooting.

\section{First-Strand cDNA Synthesis}

20. Add $1 \mu \mathrm{L}$ random primers $(0.05 \mathrm{mg} / \mathrm{mL})$ to the $4 \mu \mathrm{L}$ of resuspended aRNA from Step 19.

21. Heat at $70^{\circ} \mathrm{C}$ in a dry bath incubator for $10 \mathrm{~min}$.

22. Immediately place on ice for at least $5 \mathrm{~min}$.

23. While keeping the sample on ice, assemble the following master mix (volumes shown for one reaction):

$2 \mu \mathrm{L}$ First-Strand Buffer $(5 x)$

$1 \mu \mathrm{L}$ DTT $(100 \mathrm{~mm})$

$0.5 \mu \mathrm{L}$ dNTP mix (10 mM)

$0.5 \mu \mathrm{L}$ RNasin $(40 \mathrm{U} / \mu \mathrm{L})$

$1 \mu \mathrm{L}$ Superscript III RT $(200 \mathrm{U} / \mu \mathrm{L})$

$5 \mu \mathrm{L}$

24. Add $5 \mu \mathrm{L}$ of master mix to each reaction, mix thoroughly by pipetting, and centrifuge briefly in a microcentrifuge.

25. Incubate at room temperature for $10 \mathrm{~min}$.

This step is required to allow extension of the short random primers before the reverse transcription reaction is performed.

26. Incubate at $42^{\circ} \mathrm{C}$ in a dry bath incubator for $30 \mathrm{~min}$.

27. Heat at $95^{\circ} \mathrm{C}$ in a dry bath incubator for 5 min to denature the RNA in DNA/RNA hybrids.

28. Place on ice for at least $5 \mathrm{~min}$.

29. Store first-strand cDNA at $-20^{\circ} \mathrm{C}$ or proceed to Step 31 .

If desired, save $1 \mu \mathrm{L}$ of second-round first-strand cDNA for PCR analysis; this represents material amplified through one round.

\section{Second-Strand cDNA Synthesis}

30. Add $2 \mu \mathrm{L} \mathrm{T7-oligo(dT)} \mathrm{primer} \mathrm{(} 10 \mathrm{ng} / \mu \mathrm{L}$ stock) to $10 \mu \mathrm{L}$ of second-round first-strand cDNA. This is a different concentration of T7-oligo $(d T)$ primer from that used in the first round. Take care when preparing working dilutions of this primer from round to round.

31. Heat at $70^{\circ} \mathrm{C}$ in a dry bath incubator for $5 \mathrm{~min}$.

32. Immediately place on ice for at least $5 \mathrm{~min}$.

33. Assemble the master mix below on ice (volumes shown for one reaction).

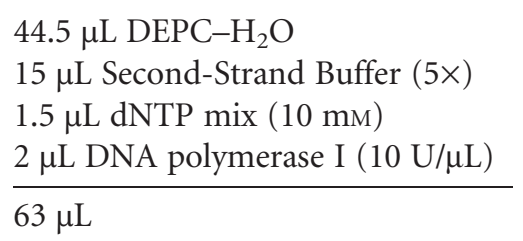

34. Add $63 \mu \mathrm{L}$ of master mix to each reaction, mix thoroughly by pipetting, and centrifuge briefly in a microcentrifuge. 
J. Morris et al.

35. Incubate at $16^{\circ} \mathrm{C}$ in a dry bath incubator for $2 \mathrm{~h}$.

36. Add $2 \mu \mathrm{L}$ of T4 DNA polymerase ( $5 \mathrm{U} / \mu \mathrm{L}$ stock).

37. Mix thoroughly by pipetting and centrifuge briefly in a microcentrifuge.

38. Incubate at $16^{\circ} \mathrm{C}$ in a dry incubator for $10 \mathrm{~min}$.

39. Proceed to Step 17 to clean up double-stranded DNA.

40. After cleanup, store the double-stranded DNA at $-20^{\circ} \mathrm{C}$ or proceed to Step 18 to synthesize aRNA from double-stranded DNA.

41. After aRNA synthesis, proceed to Step 19 to clean up the aRNA.

To assess proper amplification, aRNA quality and quantity can be assessed using an Agilent 2100 Bioanalyzer and an RNA 6000 Pico Kit. Figure 2 shows a representative Agilent Bioanalyzer 2100 RNA 6000 Pico Kit electropherogram of second-round aRNA. See Troubleshooting.

42. Immediately proceed to Step 44.

Clean aRNA can be stored at $-80^{\circ} \mathrm{C}$ for several weeks, but it is ideal to continue through the procedure until the sample is in a form of DNA, which is much more stable.

\section{Round 3}

\section{First-Strand cDNA Synthesis}

43. Add $1 \mu \mathrm{L}$ random primers $(0.05 \mathrm{mg} / \mathrm{mL}$ stock $)$ to the $4 \mu \mathrm{L}$ of resuspended aRNA.

44. Heat at $70^{\circ} \mathrm{C}$ in a dry incubator for $10 \mathrm{~min}$.

45. Immediately place on ice for at least $5 \mathrm{~min}$.

46. While keeping the sample on ice, make the master mix below (volumes shown are for one reaction).

$2 \mu$ L First-Strand Buffer $(5 \times)$

$1 \mu \mathrm{L}$ DTT $(100 \mathrm{~mm})$

$0.5 \mu \mathrm{L}$ dNTP mix $(10 \mathrm{~mm})$

$0.5 \mu \mathrm{L}$ RNasin $(40 \mathrm{U} / \mu \mathrm{L})$

$1 \mu \mathrm{L}$ Superscript III RT $(200 \mathrm{U} / \mu \mathrm{L})$

$5 \mu \mathrm{L}$

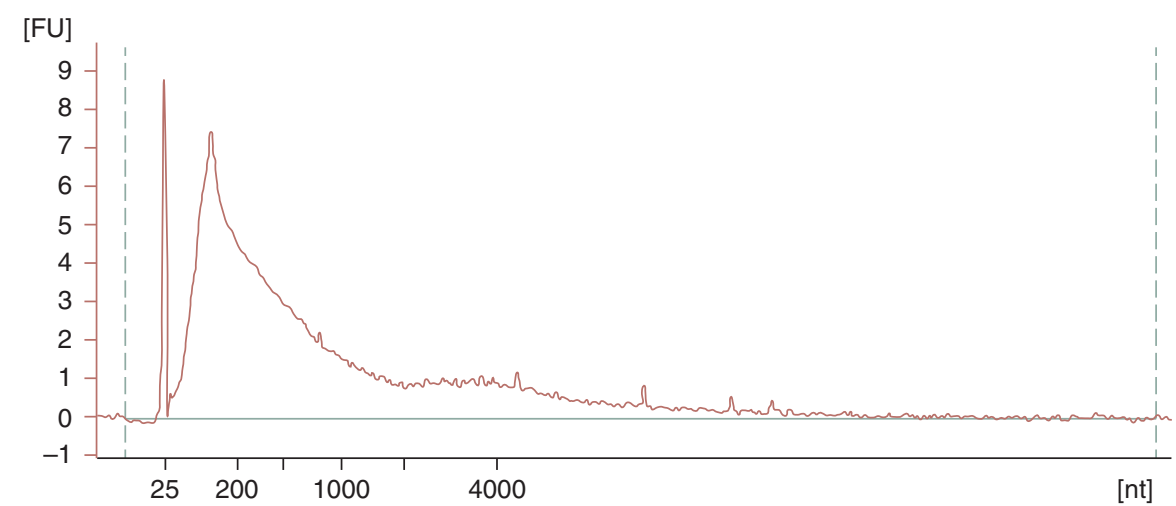

FIGURE 2. Representative Agilent Bioanalyzer 2100 RNA 6000 Pico Kit electropherogram of second-round aRNA. A single neuron was isolated using a micropipette and the mRNA from this single cell was then amplified through two rounds of the aRNA procedure. The quality of this aRNA was assessed by loading it onto an Agilent Bioanalyzer 2100 RNA 6000 chip. A successful amplification will appear on the electropherogram as a high-amplitude large, wide peak. The size of the products is indicated in nucleotides [nt] on the abscissa, while the arbitrary fluorescence units [FU] are indicated on the ordinate axis. Fluorescence units are used by the Agilent Bioanalzyer 2100 software to calculate the total nucleic acid concentration based on the corresponding fluorescence units of a known molecular mass nucleic acid marker. 
47. Add $5 \mu \mathrm{L}$ of master mix to each sample, mix thoroughly by pipetting, and centrifuge briefly in a microcentrifuge.

48. Incubate at room temperature for $10 \mathrm{~min}$.

This step is required to allow extension of the short random primers before the reverse transcription reaction is performed.

49. Incubate at $42^{\circ} \mathrm{C}$ in a dry incubator for $30 \mathrm{~min}$.

50. Heat at $95^{\circ} \mathrm{C}$ in a dry incubator for 5 min to denature the RNA in DNA/RNA hybrids.

51. Place on ice for at least $5 \mathrm{~min}$.

52. Assess the success of amplification using an Agilent 2100 Bioanalyzer and a High Sensitivity DNA Kit. If the quantity and quality of the amplified material is adequate, proceed to PCR analysis in Step 55.

Alternatively, first strand $\mathrm{CDNA}$ can be stored at $-20^{\circ} \mathrm{C}$.

See Troubleshooting.

\section{Second-Strand cDNA Synthesis}

53. If desired, complete a third round of amplification by following Steps 30-52.

If the material is to be analyzed by microarray, replace the NTPs in the in vitro transcription reaction with biotinylated NTP mix. If the material is to be analyzed by next-generation sequencing, follow the protocol through three rounds of amplification before library construction. In each case, samples have been successfully analyzed with as low as $500 \mathrm{ng}$ of total labeled aRNA for microarray analysis or $500 \mathrm{ng}$ of RNA input into library construction.

\section{PCR Analysis of cDNA}

See Figure 3 for a schematic of this PCR amplification procedure.

54. Dilute the cDNA sample $1 / 4$ with DEPC- $\mathrm{H}_{2} \mathrm{O}$.

For example, if $1 \mu \mathrm{L}$ of $\mathrm{CDNA}$ was reserved, add $3 \mu \mathrm{LDEPC}-\mathrm{H}_{2} \mathrm{O}$.

First-strand CDNA from any stage in the aRNA amplification procedure can be used for $P C R$ analysis as long as the amount of $C D N A$ reserved is replaced by $D E P C-H_{2} \mathrm{O}$ in the enzymatic reactions to preserve the appropriate reaction volume.

55. Assemble the following master mix on ice (volumes shown are for a single reaction):

$$
\begin{aligned}
& 22 \mu \mathrm{L} \text { Platinum PCR SuperMix } \\
& 1 \mu \mathrm{L} 5^{\prime} \text { primer }(10 \mu \mathrm{M}) \\
& 1 \mu \mathrm{L} 3^{\prime} \text { primer }(10 \mu \mathrm{M}) \\
& 24 \mu \mathrm{L} / \text { sample }
\end{aligned}
$$

56. For each sample that will be run, pipette $24 \mu \mathrm{L}$ of the PCR master mix into a new $0.2-\mathrm{mL}$ PCR tube. Add $1 \mu \mathrm{L}$ of the 1/4 dilution of cDNA to the appropriate PCR tube. Flick the tubes to mix.

57. Enter the following program into a thermocycler:

$\begin{array}{lrr}1 \text { cycle } & 94^{\circ} \mathrm{C} & 2 \mathrm{~min} \\ 40 \text { cycles } & 94^{\circ} \mathrm{C} & 1 \mathrm{~min} \\ & \text { Anneal } & 0.5 \mathrm{~min} \\ & 72^{\circ} \mathrm{C} & 1.5 \mathrm{~min} \\ 1 \text { cycle } & 72^{\circ} \mathrm{C} & 7 \text { min } \\ 1 \text { cycle } & 4^{\circ} \mathrm{C} & \text { Forever }\end{array}$

58. Place the samples into the thermocycler and run the program.

59. After the program has completed, run the samples out on an ethidium bromide-stained $1.5 \%$ agarose gel. Visualize the PCR product bands using a standard gel imager.

See Troubleshooting. 


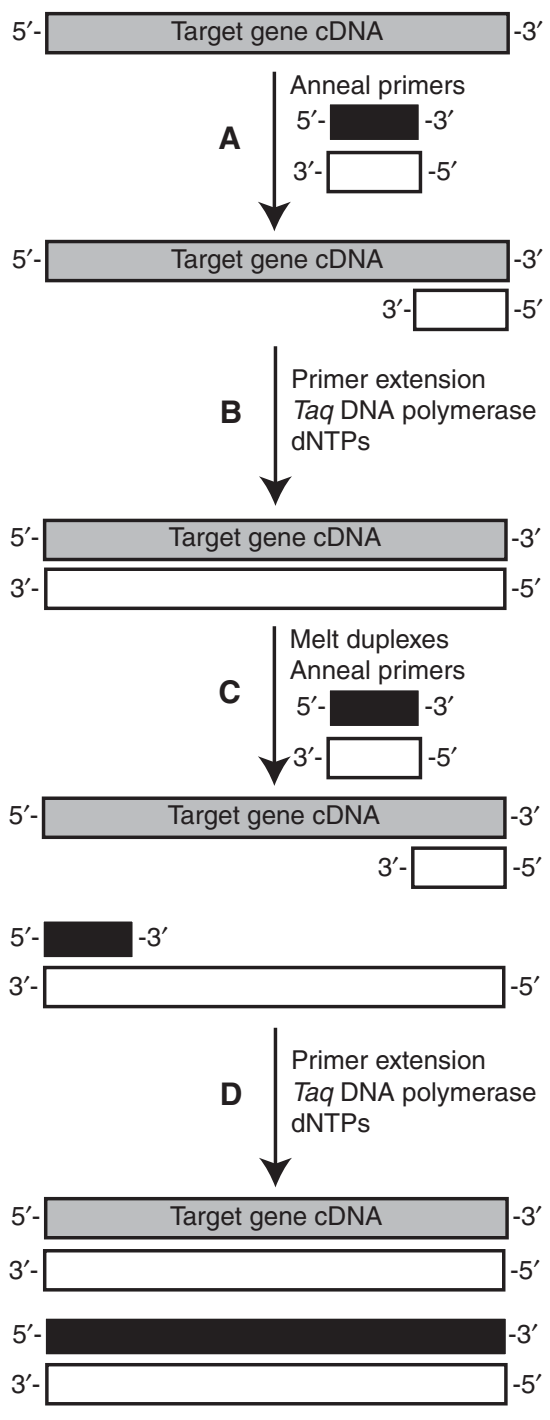

FIGURE 3. Schematic of PCR amplification of a specific aRNA amplified cDNA. Following conversion of total cell mRNA into cDNA or amplification of mRNA through two rounds of amplification followed by CDNA synthesis, a particular gene of interest can be amplified by PCR. (A) The downstream primer (white) anneals to the target gene cDNA during the annealing step. (B) This primer is extended by Taq DNA polymerase using the cDNA as a template for instructing dNTP incorporation, resulting in a full length duplex. $(C)$ This duplex is melted and primers are annealed again. $(D)$ Primers are again extended and the cycle from $(C)$ to $(D)$ is repeated for 38 cycles.

Problem (Step 19.xxii): aRNA will not easily dissolve following precipitation.

Solution: RNA can be very difficult to solubilize if it has been dried for too long. Heating briefly at $65^{\circ} \mathrm{C}$ usually solves this problem. If a white precipitate is still observed, it might possibly not be RNA. If the MegaClear columns are spun at too high a speed, the fibers of the column will begin to disperse into the solution. These fibers will appear as a cloudy white precipitate, similar to undissolved RNA. Spinning at the recommended or lower speed will prevent this from occurring.

Problem (Steps 41 and 52): No aRNA or cDNA product is observed using the RNA 6000 Pico or DNA High Sensitivity Kits or a low molecular mass smear is observed.

Solution: There are many factors that can contribute to a failed single-cell amplification. Obviously, if there is no starting material present, there will not be any detectable amplified material. It is important that the cell isolation procedure is verified to be reliable. Another common cause is RNA degradation. A low molecular mass smear is usually caused by degradation of the RNA at a later point in the protocol. When handling RNA, be sure to take extra care not to introduce 
nucleases into reagents and other consumables that will come in contact with it. Nucleases are present on skin and in secretions such as saliva so gloves should always be worn and avoid talking over tubes. If the source of nuclease contamination cannot be identified, it is best to begin again with fresh reagents and consumables. For this reason, it is important to aliquot buffers and other reagents (excluding enzymes). It is always good to run controls that contain nanogram amounts of initial RNA. If these controls appear as small molecular mass smears, then degradation is the problem. If these controls are not successfully amplified, then there might be a problem with one of the reagents or reagents might have been added out of sequence.

Problem (Step 59): No PCR product is observed.

Solution: If primers have been properly designed and barring any problems with reagents, a PCR product might or might not be observed. A single cell contains picogram amounts of total mRNA and the species targeted by the PCR primers represents an even smaller fraction of this total. For this reason, a failed single-cell PCR reaction can never be interpreted as the absence of the target. The correct interpretation is that the level of the target is undetectable for that cell at the time point assessed. Nested PCR can be performed in which the amplicon is further amplified using primers that target areas within this amplicon to confirm the presence of the target. Problems with reagents can be ruled out by running PCR on material from the same cell using primers targeted to a highly abundant mRNA such as GAPDH (neurons).

More than 20 years ago, the aRNA amplification and RT-PCR procedures were first used to couple transcriptomics and functional analysis at the single-cell level (Bargas 1994; Eberwine 1992). Since their initial reports, the aRNA amplification and single-cell RT-PCR procedures are still the most universally used methods by scientists to connect single-cell transcriptional fingerprints and physiological phenotypes (Morris 2011). Overall, the aRNA approach offers a greater utility to scientists. The aRNA procedure provides the complete transcriptional fingerprint of a single cell and can be paired with several advanced downstream experimental procedures: RNA Seq, microarrays, macroarrays, and antibody positioned RNA amplification (Eberwine 1992; Kelz 2002; Kamme 2003; Davis 2004; Ginsberg 2004). Most importantly, the aRNA procedure delivers a linear amplification of the mRNA population, so scientists can apply the procedure to quantitatively study the entire transcriptome of an individual cell or distinct subcellular regions of cells such as neuronal dendrites (Kacharmina 1999). The aRNA procedure is limited only by the fact that the captured mRNA profile is predominately limited to the $3^{\prime}$ region of the transcript when oligo-dT priming is used. Therefore, mRNA sequences that are over thousands of nucleotides away from the mRNA poly(A)-tail region can be technically challenging to study.

The single-cell RT-PCR procedure was the first method to correlate molecular analysis at the single-cell level with ionic currents in neurons (Bargas 1994; Eberwine 2011). In contrast with the aRNA method, the single-cell RT-PCR procedure targets only a limited number of transcripts, so the vast majority of the transcriptional profile is completely unidentified. However, it does provide scientists with the opportunity to target and amplify select sequence regions of mRNA. This makes single-cell RT-PCR a favored option for analyzing splice variant profiles and $5^{\prime}$ regions of mRNA transcripts. Although only a small number of transcripts can be analyzed with single-cell RT-PCR, its chief advantages lie in being relatively inexpensive and allowing larger amounts of continuous mRNA sequence (well over 1,000 nucleotides) from an individual transcript to be obtained. This feature provides scientists with additional transcriptional data such as the expressed exonic combinations and retained-intronic sequences for their target mRNA transcript (Bell 2008; Buckley 2011). However, primer design can be a limiting factor as the target sequence must not be overly $\mathrm{G}-\mathrm{C}$ rich to permit high-quality PCR primers to be placed in the appropriate regions of the target mRNAs. In addition, the single-cell RT-PCR approach yields an exponential amplification, so quantification of target 
J. Morris et al.

mRNA levels is always more difficult (Eberwine 1992). Regardless of these small limitations, these techniques combined provide a powerful method for cataloging and characterizing the mRNA species within a given cell of interest and a means for studying how the level and identity of these transcripts differ from cell to cell as well as following different pharmacological treatments.

\section{RECIPE}

DEPC- $\mathrm{H}_{2} \mathrm{O}$

Mix $1 \mathrm{~mL}$ of DEPC (diethyl pyrocarbonate) with $1000 \mathrm{~mL}$ of water in a screw-cap glass bottle. Incubate for $\sim 2 \mathrm{~h}$ at room temperature in a fume hood with occasional swirling. Autoclave. Store at room temperature for up to $12 \mathrm{mo}$.

\section{REFERENCES}

Bargas J, Howe A, Eberwine J, Cao Y, Surmeier DJ. 1994. Cellular and molecular characterization of $\mathrm{Ca}^{2+}$ currents in acutely isolated, adult rat neostriatal neurons. J Neurosci 14: 6667-6686.

Bell TJ, Miyashiro KY, Sul JY, McCullough R, Buckley PT, Jochems J, Meaney DF, Haydon P, Cantor C, Parsons TD, et al. 2008. Cytoplasmic $\mathrm{BK}(\mathrm{Ca})$ channel intron-containing mRNAs contribute to the intrinsic excitability of hippocampal neurons. Proc Natl Acad Sci 105: 1901-1906.

¿. Buckley PT, Lee MT, Sul JY, Miyashiro KY, Bell TJ, Fisher SA, Kim J, Eberwine J. 2011. Cytoplasmic intron sequence-retaining transcripts can be dendritically targeted via ID element retrotransposons. Neuron 69: 877-884.

Davis JE, Eberwine JH, Hinkle DA, Marciano PG, Meaney DF, McIntonsh TK. 2004. Methodological considerations regarding single-cell gene expression profiling for brain injury. Neurochem Res 29: 1113-1121.

Eberwine J, Bartfai T. 2011. Single cell transcriptomics of hypothalamic warm sensitive neurons that control core body temperature and fever response: Signaling asymmetry and an extension of chemical neuroanatomy. Pharmacol Ther 129: 241-259.
Eberwine J, Yeh H, Miyashiro K, Cao Y, Nair S, Finnell R, Zettel M, Coleman P. 1992. Analysis of gene expression in single live neurons. Proc Natl Acad Sci 89: 3010-3014.

Ginsberg SD, Elarova I, Ruben M, Tan F, Counts SE, Eberwine JH, Trojanowski JQ, Hemby SE, Mufson EJ, Che S. 2004. Single-cell gene expression analysis: Implications for neurodegenerative and neuropsychiatric disorders. Neurochem Res 29: 1053-1064.

Kacharmina JE, Crino PB, Eberwine J. 1999. Preparation of cDNA from single cells and subcellular regions. Methods Enzymol 303: 3-18.

Kamme F, Salunga R, Yu J, Tran D, Zhu J, Luo J, Bittner A, Guo H, Miller N, Wan J, et al. 2003. Single-cell microarray analysis in hippocampus CA1: Demonstration and validation of cellular heterogeneity. J Neurosci 23: 3607-3615.

Kelz MB, Dent GW, Therianos S, Marciano PG, McIntosh TK, Coleman PD, Eberwine JH. 2002. Single-cell antisense RNA amplification and microarray analysis as a tool for studying neurological degeneration and restoration. Sci Aging Knowl Environ 2002: pre1-10.

Morris J, Singh JM, Eberwine JH. 2011. Transcriptome analysis of single cells. J Vis $\operatorname{Exp}(50)$, e2634. doi: 10.3791/2634. 


\section{Antisense RNA Amplification for Target Assessment of Total mRNA from a Single Cell}

Jacqueline Morris, Thomas J. Bell, Peter T. Buckley and James H. Eberwine

Cold Spring Harb Protoc; doi: 10.1101/pdb.prot072454

\begin{tabular}{rc}
$\begin{array}{r}\text { Email Alerting } \\
\text { Service }\end{array}$ & Receive free email alerts when new articles cite this article - click here. \\
\hline $\begin{array}{c}\text { Subject } \\
\text { Categories }\end{array}$ & Browse articles on similar topics from Cold Spring Harbor Protocols. \\
& Analysis of Gene Expression (197 articles) \\
& Analysis of Gene Expression, general (129 articles) \\
& mRNA (132 articles) \\
& Polymerase Chain Reaction (PCR) (139 articles) \\
& Polymerase Chain Reaction (PCR), general (184 articles) \\
& RNA (317 articles) \\
\hline
\end{tabular}

